\title{
SENI BELA DIRI EWA WUNA DI KECAMATAN LASALEPA KABUPATEN MUNA ${ }^{1}$
}

\author{
Oleh \\ Abd. Akbar H. ${ }^{2}$ \\ La Batia ${ }^{3}$
}

\begin{abstract}
ABSTRAK: Tujuan utama penelitian ini adalah: Untuk menjelaskan syarat, mendeskripsikan gerakan, menjelaskan perubahan yang terjadi dalam seni bela diri Ewa Wuna, dan untuk menggali serta mengungkapkan nilai- nilai yang terkandung dalam seni bela diri Ewa Wuna di Kecamatan Lasalepa Kabupaten Muna.

Hasil penelitian menunjukkan tahap dalam memasuki perguruan Seni Bela Diri Ewa Wuna ada dua syarat: (1) Feoti depake parakano dana banggai be lomo Tujuanya agar mata menjadi tajam dan tidak takut terhadap benda- benda tajam, kedua dofokadiu nekontu kaghito, Tujuannya agar sang murid selalu taat kepada perintah Tuhan dan menjungjung nilai- nilai yang diajarkan oleh sang guru. (2) Setelah syarat diterima dan di setujui oleh murid, maka guru mulai membimbing murid melakukan gerakan dasar silat, di mana gerakan dasar ini terdiri atas dua tahap, yaitu: a. Gerakan pica bunga, langkah satu, langkah dua, langkah tiga, langkah empat, b. Gerakan menyerang dan bertahan. (3) Perubahan yang terjadi dalam seni bela Ewa Wuna mengalami perubahan, antara lain dari segi pakaian dan fungsinya dimana periode pada masa kerajaan hanya menggunakan pakaian serba hitam dan diikatkan sarung Muna sedangkan sekarang pakaian yang digunakan hanya pakaian biasa, seperti pakaian modern yang kadang memakai sarung Muna di pinggang dan kadang tidak. 4.Untuk menggali dan mengungkapkan nilai-nilai yang terkandung dalam seni bela diri Ewa Wuna di kecamatan Lasalepa Kabupaten Muna.
\end{abstract}

\section{Kata Kunci: Syarat, Gerak, Perubahan, Ewa Wuna}

\section{PENDAHULUAN}

Silat tradisional telah eksis dikalangan masyarakat di Indonesia. silat tradisional telah ada seiring dengan lahirnya bangsa Indonesia, dimana kala itu silat digunakan untuk mempertahankan diri terhadap serangan musuh. Pada masa sekarang silat fungsinya sedikit bergeser tidak hanya digunakan sebagai pertahanan diri tetapi juga sebagai olahraga. Silat sebenarnya syarat akan spiritual, kita ketahui bahwa silat berasal dari bahasa Arab shatsalam-ia yang artinya sholat, silaturahim. Jadi sebenarnya silat yang di dukung dengan sholat itu baik dan silat tanpa silaturahim juga tidak sempurna.

Kabupaten Muna Kecamatan Lasalepa salah satu kabupaten yang ada di Sulawesi Tenggara, selain memiliki wilayah yang kaya jambu mete, batu kapur, juga memiliki sumberdaya budaya dan sejarah yang cukup banyak diantaranya Ewa Wuna (Silat Muna) merupakan salah satu sumber daya budaya yang harus dilestarikan. Permainan Ewa Wuna (Silat Muna) ini selalu dipertunjukan oleh masyarakat Muna dalam suatu acara adat, seperti pada adat upacara perkawinan, syukuran dan lain sebagainya. Berdasarkan uraian tersebut menunjukan bahwa permainan Ewa Wuna (Silat Muna) ini haruslah diterapkan kepada masyarakat maupun pemerintah daerah. Jika kita tinjau dari aspek budaya dan

\footnotetext{
${ }^{1}$ Disandur dari hasil penelitian

${ }^{2}$ Alumni Jurusan Pendidikan Sejarah

${ }^{3}$ Dosen FKIP UHO
} 
nilai-nilai yang terkandung dalam permainan Ewa Wuna (Silat Muna) ini banyak hal yang dapat kita ambil atau petik.

Permainan Ewa Wuna (Silat Muna) ini jika kita bandingkan dengan silat pada umumnya memiliki perbedaan terutama pada gerakanya. Bedanya dengan silat pada umumnya jurus-jurus yang digunakan pada permainan Ewa Wuna (Silat Muna) ini seluruh anggota tubuh turut berperan sehingga gaya dan gerak yang cukup indah dan sangat menarik. Bukan hanya itu saja, masih banyak nilai-nilai yang dapat diambil dalam permainan Ewa Wuna (Silat Muna) ini.

Selain itu, kebudayaan asing juga turut mempengaruhi dimana para generasi lebih suka mengatraksikan belah diri lain seperti Karate, Taekwondo, dan lain-lain, dari pada melakukan permainan Ewa Wuna (Silat Muna). Hal inilah yang menjadi keprihatinan penulis, sehingga menurut penulis perlu ditanamkan kembali makna budaya permainan Ewa Wuna (Silat Muna) pada generasi muda agar nantinya budaya permainan Ewa Wuna (Silat Muna) ini sebagai warisan leluhur tidak tergantikan oleh budaya luar yang jauh dari ciri khas masyarakat Muna. Permainan Ewa Wuna (Silat Muna) ini dalam prosesi pelaksanaannya secara ritual berdasarkan budaya masyarakat Muna masih dilaksanakan di Kecamatan Lasalepa.

Sementara itu, nilai-nilai luhur warisan budaya yang terkandung didalam permainan Ewa Wuna (Silat Muna) seperti nilai bahasa, nilai relijius, nilai moral, nilai seni, nilai sosial dan nilai budaya dan masih tetap terpelihara dan dijaga kelestarianya sebagai bagian dari warisan leluhur. Untuk itulah agar permainan Ewa Wuna (Silat Muna) ini dan nilainilai yang terkandung dalam silat ini tetap terjaga dan tidak dilupakan begitu saja oleh generasi muda, maka perlu dilakukan suatu tindakan kongkrit dengan melakukan penelitian secara ilmiah tentang permainan Ewa Wuna (Silat Muna) itu sendiri. Melihat banyak nilai-nilai yang dapat diambil untuk terus dilestarikan dan dikembangkan dalam permainan Ewa Wuna ini, maka perlu dikaji secara empiris.

\section{KAJIAN PUSTAKA}

Secara sederhana, kebudayaan dapat diartikan sebagai cara hidup atau dalam bahasa inggrisnya "way of life". Cara hidup atau pandangan itu meliputi cara berpikir, cara berencana dan cara bertindak, disamping segala hasil karya nyata yang dianggap berguna, benar dan dipatuhi. Ada beberapa pendapat para ahli dimana satu sama lain memberikan penafsiran yang berbeda-beda. Soekanto (1990:187) menyatakan bahwa"Kebudayaan berasal dari Bahasa Sansekerta yaitu Buddhayah yang merupakan bentuk jamak dari kata budi atau akal".

Koentjaraningrat (1974:54) mendefenisikan kebudayaan sebagai keseluruhan gagasan dan karya manusia yang harus dibiasakan dengan belajar, beserta keseluruhankeseluruhan dari seluruh hasil budi dan karyanyaitu. Kebudayaan itu sesungguhnya dimiliki oleh setiap masyarakat, tidak ada suatu masyarakat yang ada hanya perbedaan latar belakang, perkembangan dengan pemanfaatan bagi kepentingan masyarakat sehingga terjadi perbedaan kemajuan peradaban. Kebudayaan tidak akan luput dari proses kehidupan manusia karena kebudayaan diciptakan oleh manusia berdasarkan kecakapanya. Koentjaraningrat (1996:72) mengemukakan pendapatnya tentang kebudayaan bahwa: "Kebudayaan adalah seluruh sistem gagasan dan rasa, tindakan, serta karya yang dihasilkan manusia dalam kehidupan bermasyarakat yang dijadikan miliknya dengan belaja. 
Karya yang dihasilkan manusia tentunya terdapat pada berbagai aspek kehidupan yang mempengaruhi cara hidup manusia baik pada kedudukanya sebagai individu maupun secara kelompok. Dari hasil inilah Kluckhon mendefenisikan kebudayaan kedalam empat (4) aspek yaitu: (1) Keseluruhan cara hidup suatu masyarakat, (2) Warisan sosial yang diperoleh individu dari kelompoknya, (3) Suatu cara berpikir,merasa dan percaya, dan (4) Suatu abstraksi dari tingkah laku. (Notowidago,1995: 5).

Permainan silat tradisional merupakan sebuah permainan yang sangat penting untuk diketahui oleh berbagai lapisan masyarakat termasuk anak-anak karena permainan tradisional mengandung pesan-pesan moral yang perlu ditanamkan pada diri seorang anak. Selain itu, permainan tradisional merupakan warisan budaya yang perlu dikembangkan dan dipertahankan sebagai salah satu kekayaan bangsa dibidang kebudayaan. Dalam Depdikbud (1996:47) permainan tradisional bisa bertahan atau dipertahankan karena pada umumnya mengandung unsur-unsur budaya dan nilai-nilai moral yang tinggi, seperti kejujuran, kecakapan, solidaritas, persatuan dan kesatuan, keterampilan dan keberanian. Sehingga dapat pula dikatakan permainan tradisional dapat dijadikan alat pembinaan nialai budaya pembangunan kebudayaan nasional Indonesia.

Para ahli memberikan pengertian yang berbeda-beda tentang nilai diantaranya menjelaskan bahwa nilai merupakan ukuran sikap dan perasaan seseorang atau kelompok yang berhubungan dengan keadaan baik, buruk, benar, salah, suka atau tidak suka terhadap suatu objek baik material maupun non material. Menurut Gazalba (1967:72) nilai itu bersifat ide karena itu abstrak, tidak dapat disentuh oleh indera yang dapat ditangkap oleh perbuatan yang mengandung nilai.

Kemampuan berubah selalu merupakan sifat yang penting dalam kebudayaaan manusia. Tanpa itu, kebudayaan tidak mampu menyesuaikan diri dengan kebudayaan yang berubah. Menurut Haviland (2004: 251) kebudayaan suatu waktu berubah karena bermacam-macam sebab, salah satu sebabnya adalah perubahan lingkungan yang dapat menuntut perubahan yang bersifat adaptif. Sebab lain adalah bahwa, melalui karena kebetulan, atau karena sebab lain.

\section{METODE PENELITIAN}

Penelitian ini dilaksanakan di Kecamatan Lasalepa Kabupaten Muna. Dengan jenis penelitian ini adalah penelitian yang bersifat kualitatif deskriptif, maka data-data yang diperoleh berdasarkan informan atau obyek yang diteliti dengan menggunakan pendekatan strukturis. Sedangkan pendekatan penelitian ini, menggunakan pendekatan strukturis yang mempelajari dua domain yakni peristiwa dan struktur sebagai satu kesatuan yang saling melengkapi. Artinya peristiwa mengandung kekuatan mengubah struktur sosial, sedangkan struktur mengandung hambatan atau dorongan bagi tindakan perubahan dalam masyarakat. Sumber data penelitian terdiri atas sumber tertulis, sumber lisan, dan visual. Metode yang digunakan dalam penelitian ini adalah metode sejarah yang mengacu pada Sjamsuddin (2007: 17), yang dibagi dalam tiga tahapan kerja yaitu, pengumpulan sumber terdiri atas penelitian kepustakaan, pengamatan, studi lisan, studi dokumen. Verifikasi yang terdiri kritik ekstern, dan kritik intern, dan Penyusunan hasil penelitian yang terdiri atas penafsiran, penjelasan, dan penyajian. 


\section{HASIL PENELITIAN DAN PEMBAHASAN}

\section{Syarat Dalam Mempelajari Seni Bela Diri Ewa Wuna di Kecamatan Lasalepa Kabupaten Muna.}

Pulau Muna memiliki beraneka ragam simbol baik dalam bentuk tulisan-tulisan maupun dalam bentuk benda. Keberadaan simbol ini menegaskan bahwa pulau Muna merupakan salah satu wilayah yang ada dinusantara. Muna memiliki perjalanan sejarah yang cukup panjang, mulai dari bentuk kerajaan-kerajaan kecil seperti Benteng Tiworo, Mesjid Muna dan masih banyak lagi benteng kecil lainnya yang belum terindentifikasi dan butuh kajian lebi lanjut. Muna juga memiliki beraneka ragam seperti, tarian, upacara, adat, dan permainan silat kampung. Dari sekian banyaknya budaya yang ada di pulau Muna penulis memiliki sala satu yakni Ewa Wuna yang masih di populerkan atau masih dikembangkan dalam masyarakat Muna khususnya di Kecamatan Lasalepa masih banyak melakukan kelompok perguruan silat.

Permainan Ewa Wuna telah lama ada dalam masyarakat Muna Kecamatan Lasalepa sebagaimana yang diungkapkan oleh informan bahwa:"Masyarakat Muna Kecamatan Lasalepa dahulu sudah mengenal permainan Ewa Wuna. Permainan ini merupakan sejenis silat tradisional dan sering di mainkan oleh masyarakat pada saat upacara adat seperti pembukaan adat perkawinan, khitanan dan lain sebagainya. ( La uma, Wawancara 23 Januari 2018 )".

Sejak dahulu masyarakat Muna Kecamatan Lasalepa telah megenal salah satu permainan silat yaitu Ewa Wuna. Dari uraian tersebut dapat di peroleh gambaran bahwa keberadaan permainan Ewa Wuna ini dijadikan sebagai oleh prajurit Kerajaan sebagai salah satu ujung tombak, dalam pemerintahan. Sebenarnya Awal Munculnya permainan Silat Ewa Wuna di Kecamatan Lasalepa Kabupaten Muna belajar dari guru La teke. Ia mengajarkan silat ini hanya pada orang-orang pilihan yang di anggapnya mampu mengemban tanggung jawab dari ilmu yang di ajarkannya untuk memperkenalkan Ilmu Bela Diri Ewa Wuna adalah La Teke yang mempunyai keahlian dan memiliki daya tangkap yang tajam.

Mempelajari Ewa Wuna memiliki dua syarat yang terlebih dahulu harus dilakukan oleh seorang murid yaitu:

1. Feoti Mata (Menetesi Mata ); Dimana yang digunakan untuk Feoti Mata atau menetesi mata ini bahan-bahan yang digunakan adalah Parakano Dana( akar alangalang ), daun kelor (Roono Banggai), dan Jeruk Nipis (Lemo Nipi). Caranya bahanbahan ini dihaluskan terlebih dahulu kemudian dicampur atau disatukan dalam satu wadah, setelah itu sang gurumenetesi kedalam mata seorang murid melalui ujung keris. Menurut kepercayaan masyarakat Muna khususnya di Kecamatan Lasalepa, tujuan dari Feoti Mata (Menetesi Mata) itu adalah agar seorang murid membersihkan badan dan dosanya serta agar penglihatanya tajam dan tidak takut terhadap bendabenda tajam. Feoti Mata ini merupakan salah satu syarat dalam mempelajari Ewa Wuna agar penglihatanya tajam dan bisa mengendalikan diri ketika melihat barang tajam di depanya, baik itu yang berniat tidak baik kepada dirinya dan orang-orang di sekelilingnya.

2. Kakadiu (Dimandikan); Setelah selesai melakukan proses Feoti Mata (Menetesi Mata), maka seorang murid dimandikan oleh sang guru di atas batu besar kemudian 
membacakan doa di depan mata murid agar selalu taat kepada sang pencipta, dan tidak menyalahgunakan seni bela diri Ewa Wuna (Silat Muna) yang dipelajarinya.

\section{Proses Mempelajari Gerakan Dasar Seni Bela Diri Ewa Wuna di Kecamatan Lasalepa Kabupaten Muna}

Setelah syarat diterima dan disetujui oleh guru, maka guru mulai membimbing murid untuk melakukan gerak silatdasar dalam hal ini Ewa Wuna. Dimana sebelum memulai gerakan permainan Ewa Wuna terlebih dahulu dilakukan pembukaan permainan silat. Tujuanya adalah menghormati orang yang lebih tua dan mempersilahkan lawan untuk memulai permainan.

Pica bunga (buka jurus) ini menggunakan media kaki dan tangan dimana dalam gerakan ini yang berperan penting adalah kaki dan tangan. Kegunaan dari pica bunga ini adalah berfungsi untuk memasang kuda-kuda yang lebih baik dalam media menggunakan kaki agar tidak gampang jatuh ketika lawan kita datang menyerang. Gerakan pica bunga ini titik tumpu serangan berada pada sisi tangan. Gerakan ini terdapat makna yang dipetik yakni bermohon kepada sang pencipta (Allah swt), yang mana mirip gerakan tangan dalam takbiratul ihram dalam shalat. Pelaksanaan gerakan seni bela diri Ewa Wuna (Silat Muna) terdiri dari 2 Tahap yaitu :

\section{Tahap Pertama}

Pada tahap pertama ini seorang murid diharuskan untuk mempelajari seni bela diri Ewa Wuna (Silat Muna) yang terdiri dari empat langka diantaranya:

a. Langkah Satu, dimana gerakan ini memasang kuda- kuda dengan baik serta diiringi dengan jurus.

b. Langkah Dua, dimana gerakan ini Mengamati gerakan lawan dan mencari letak kelemahan serta sambil melakukan serangan-serangan pukulan tangan diiringi dengan kuda-kuda yang baik.

c. Langkah Tiga, dimana gerakan ini menyerang lawan/musuh serta melakukan gerakan cepat yang dapat mencederai lawan.

d. Langkah Empat, dimana dalam gerakan langkah empat ini yang banyak berperan adalah tangan dan kaki sementara posisi tangan di kepal kedalam terus dilancarkan dengan pukulan lurus kedepan dan disertai dengan kaki membentuk kuda-kuda yang berfungsi untuk mempertahankan posisi tubuh agar setiap serangan yang akan dilakukan dapat dihindari dan melakukan pukulan lurus tepat mengenai sasaran sehingga menjatuhkan lawan tanpa bergerak sedikitpun.

\section{Tahap Kedua}

Seperti halnya dalam tahap pertama, pada tahap kedua juga seorang murid mempelajari seni bela diri Ewa Wuna (Silat Muna) terdiri dari empat gerakan menyerang lawan diantaranya adalah :

a. Fokantibae Welalo (Sasaran Kedalam); Fokantibae welalo merupakan gerakan menyerang yang berasal dari dalam, dimana dalam gerakan ini seorang pemain seni bela diri Ewa Wuna (Silat Muna) akan melakukan serangan dengan memasuki area lawan. Sasaran serangan ini adalah titik fital yang dianggap dapat melumpuhkan musuh dalam satu kali serangan. Gerakan ini berupa pukulan lurus kedepan yang dilapisi dengan gerakan langkah Empat sebagai pertahanan mengantisipasi serangan dari lawan secara tiba-tiba. 
b. Fokantibae Weluara (Sasaran Diluar); Sebagaimana halnya gerakan fokantibae welalo dan fokantibae wesimbeli atau gerakan dari luar berupa pukulan lurus kedepan samping atau luar lawan. Gerakan ini juga tetap dilapisi dengan langkah empat sebagai mengantisipasi serangan lawan. Gerakan ini juga membutuhkan peranan tubuh ketahanan posisi kaki yang kokoh agar pukulan dan serangan yang dilakukan lebih kuat dan terarah.

c. Fokantibae Deputara Welalo be Weluara (Sasaran memuatar didalam dan diluar); Sasaran memutar kedalam dan diluar ini merupakan gerakan kombinasi, gerakan ini merupakan gerakan sulit yang dilakukan dalam setiap permainan silat kampung. Gerakan ini merupakan gerakan lurus kedepan, pukulan pendek dengan siku, pukulan pendek setelah lawan ditarik dengan posisi badan menghadap kelawan dan menariknya kedepan lalu dilanjutkan lagi pukulan akhir.; Fokantibae Dosowo be Dosuli Nekaletehano (Sasaran mundur dan menghindar dan kembali kesasaran)

Dari sekian banyaknya gerakan yang dilakukan dalam seni bela diri Ewa Wuna (Silat Muna), gerakan ini merupakan gerakan yang paling sulit dilakukan. Gerakan katumbu tewise (gerakan pukulan kedepan ) lalu disertai gerakan mundur selangkah kebelakang, kemudian dilanjutkan dengan pukulan kembali kesasaran lawan. Keempat gerakan diatas dilakukan sekaligus, fungsi gerakan tersebut adalah sebagai benteng penyerangan disaat lawan menyerang, maka yang berfungsi adalah mundur kemudian dilanjutkan lagi pukulan sasaran kearah lawan. Jika masih ada yang selamat dengan serangan ini, berarti masih beruntung orang tersebut karena serangan ini merupakan serangan yang mematikan.

\section{Perubahan Yang Terjadi Dalam Seni Bela Diri Ewa Wuna di Kecamatan Lasalepa Kabupaten Muna.}

Sejalan dengan kemajuan dan perkembangan ilmu pengetahuan dan teknologi yang dialami oleh masyarakat dan pendukungnya, maka kebudayaan ini juga mengalami beberapa perubahan-perubahan dari unsur-unsur pelaksanaannya. Setiap unsur budaya yang telah lama berkembang didalam suatu masyarakat selalunya akan mengalami perubahan yang sesuai kondisi masyarakat dan pendukungnya, demikian pula halnya dengan seni bela diri Ewa Wuna di kecamatan Lasalepa kabupaten Muna. Konon, Ewa Wuna pertama kali di kembangkan oleh baginda LaKilaponto (Raja Muna sekaligus sultan Buton yang pertama). Dialah yang menciptakan, menyebarkan ilmu silat Ewa Wuna. Sebagai orang yang menguasai ilmu bela diri Ewa Wuna. Lalu menyebarkannya dilingkungan keluarga, kerabat di istana hingga keluar negri seperti China. Dikisakan Raja La kilaponto menyebarkan seni bela diri Tinda lalo merupakan dasar dari ilmu silat Muna, dari jazirah Sulawesi, jawa, sumatera. Dengan keberanian dan keperkasaanya, beliau mengajarkan dan menyebarkan seni bela diri keseantero Asia.

Untuk itula diyakini Seni bela Diri kungfu China yang masyhur itu merupakan keturunan ajaran seni bela diri Tinda lalo. Ketika berada ditangan para biksu-biksu wihara, seni bela diri tinda lalo menjelma sebagai sikap hidup. Untuk mengetahui lebih jelas tentang perubahan yang terjadi dalam seni bela diri Ewa Wuna di Kecamatan Lasalepa Kabupaten Muna maka dibagi dalam dua periode yaitu periode pada masa kerajaan dan pada masa sekarang.

\section{Periode pada masa kerajaan}

Berdasarkan hasil penelitian atau data-data yang yang telah dikumpulkan, bahwa informan yang bernama La Uma yang pasti tentang masuknya seni bela diri Ewa Wuna 
(Silat Muna) di Kecamatan Lasalepa yaitu pada abad 18 masehi seni bela diri Ewa Wuna (Silat Muna) diperkenalkan di daerah Muna. Oleh karena itu diperiode ini belum mengalami perubahan dan tetap dilaksanakan sesuai ketentuan atau aturan yang telah dibuat pada awal lahirnya seni bela diri Ewa Wuna. Silat Tradisional Ewa Wuna pada masa kerajaan berfungsi sebagai bela diri atau pertahanan diri dari gangguan para penjahat atau penjajah. Informan La suli menuturkan bahwa: Dari segi nama dan gerakan tidak terjadi perubahan pada silat tradisional Ewa Wuna ini masi sama. kemudianaksesoris dan pakaian yang di gunakan pesilat pada periode pada masa kerajaan Muna, hanya memakai Celana hitam, Baju hitam, dan di ikatkan sarung Muna di pinggang. Selain itu juga pada periode masa Kerajaan Muna yang belajar Silat Ewa Wuna hanya orang-orang tertentu saja. Disini jelas di periode ini Silat Ewa Wuna belum mengalami perubahan baik dari nama, pakaian, gerakan, ataupun fungsi silat itu sendiri. Kemudian pada zaman kerajaan Ewa Wuna di jadikan sebagai silat atau pertaanan diri bagi keluarga kerajaan dan di jadikan pertahanan dalam artian prajurit di ajarkan silat tersebut. Misalnya: Muna memiliki organisasi angkatan perang, dimana angkatan perang tersebut dapat dinilai seberapa solid dan lengkapnya organisasi militer serta dukungan alat utama system pertahanan yang dimilikinya. Suatu Negara/Kerajaan bisa di anggap sebagai kerajaan yang kuat serta di segani oleh kerajaan tetangganya apabila memiliki angkatan perang yang solid, terorganisir, dan dilengkapi dengan alusista yang mumpuni.

Organisasi dan sisitem pertahanan yang perna dimiliki kerajaan Muna yaitu: Kapitalao (panglima agkatan perang) adalah panglima angkatan Muna yang membawahi 6 komando militer masing-masing 1 kapita panglima darat, 1 kapitalao matagholeo (panglima armada laut bagian timur), 1 kapitalao kansopa (panglima armada laut bagian barat), dan 3 bharata (komando daerah pertahanan laut) yang dikenal dengan bharata Tolu peleno.

Tugas dari seorang kapitalao adalah melakukan peroganisian satuan-satuan komando dibawahnya, bertanggung jawab aras keamanan dan pertahanan dan keselamatan omputo (Raja) dan seluruh perangkat kerajaan. Kapitalao memakai daster dan seragam kebesaran militer seorang panglima, bersenjatakan panglima kebesaran yang dijuluki la wiira ningai mearono tapuaka (si penangkal isu, si penyapu badai bagai tsunami), dan semua perangkat kerajaan diajarkan pencak silat Ewa Wuna.

\section{Periode Sekarang}

Budaya merupakan bagian dari kehidupan masyarakat sebagai hasil cipta, rasa dan karsa manusia yang dimiliki bersama dari anggota-anggota masyarakat. Dari segi nama menurut pengetahuan informantidak terjadi perubahan pada seni bela diri Ewa Wuna (Silat Muna) masih sama nama yang digunakan pada masa kerajaan sedangkan dari segi gerakan silat tergantung dari diri kita masing-masing untuk mengubah dan memperindah agar lebih indah lagi dan menarik untuk dinikmati oleh para penonton. Dari segi fungsi pada masa kerajaan hanya digunakan sebagai alat pertahanan diri sedangkan pada masa perkembangan selanjutnya atau periode sekarang permainan seni bela diri Ewa Wuna dilaksanakan ketika ada kegiatan besar misalnya: Perkawinan, Cukur rambut, Penyambutan tamu pemerintahan dan lain sebagainya. Kemudian dari segi pakaian atau aksesoris dahulu hanya berpakaian baju hitam, celana hitam dan di ikatkan sarung Muna di pinggang. Kemudian pada masa sekarang ini hanya memakai pakaian biasa seperti pakaian modern yang kadang di ikatkan sarung Muna di pinggang kadang juga tidak. Saat tampil di acara-acara adat lainya seperti acara perkawinan, khitanan dan lain sebagainya. Dahulu pada masa kerajaan tidak diiringi dengan Musik dan Gong. Kini pada periode sekarang 
permainan Silat Ewa Wuna ini diiringi dengan gendang dan gong ini bisa mengatur gerakan tarian Silat Ewa Wuna lebih indah lagi. Dahulu hanya diajarkan pada orang-orang tertentu saja, namun skarang semua orang bisa melakukan permainan silat ini baik dari anak-anak, orang dewasa, maupun orang tua. Kemudian permainan Ewa Wuna di peragakan saat menyambut kedatangan kandidat pemimpin yang mana budaya ini masih dipertahankan eksistensinya. Dahulu diadakan upacara seperti pernikahan, akiqah, atau penyambutan tamu seperti Raja.

\section{Nilai-Nilai Yang Terkandung Dalam Permainan Seni Bela Diri Ewa Wuna (Silat Muna) di Kecamatan Lasalepa Kabupaten Muna}

Menurut Bagong Kusudirjo (1978 ); dalam Hasanudin, (2000: 3) nilai sering dirumuskan dalam konsep yang berbeda-beda penafsiran dari sudut pandang tentang keinginan, kebutuhan, kesenangan seseorang sampai pada sangsi dan tekanan masyarakat. Berdasarkan uraian tersebut maka nilai-nilai yang terkandung dalam permainanseni bela diri Ewa Wuna ini terdiri dari nilai agama, nilai seni, nilai etika, nilai sosial dan budaya. Nilai yang dimaksud dalam penelitian ini adalah mengacu pada sifat-sifat atau hal-hal yang penting atau berguna bagi manusia. Begitu juga halnya dengan nilai-nilai yang terkandung dalam permainan seni bela diri Menurut kementrian pendidikan dan kebudayaan:

a. Religius; yaitu sikap ketaatan dan kepatuan teradap agama yang dianutnya serta memiliki toleransiteradap agama lain. La. Suli mengemukakan bawa seorang ahli silat akan selalu taat kepada Tuan yang Maha Esa dan akan menjauhi semua laranganya karena dalam hatinya sudah tumbuh ketaatan dan kesadaran.

b. Jujur; yaitu perilaku yang didasarkan pada upaya menjadikan dirinya sebagai orang yang selalu dapat dipercaya dalam perkataan, tindakan dan pekerjaan. La suli mengemukakan bahwa ketika seorang mempelajari silat maka akan selalu ditanamkan pada dirinya perilaku jujur, baik dalam perkataan maupun perbuatan.

c. Toleransi; yaitu sikap dan tindakan yang mengargai perbedaan Agama, Suku, Etnis, Pendapat, Sikap, dan tindakan orang lain yang berbeda dari dirinya. La juli mengemukakan seorang pesilat akan selalu tertanam pada dirinya rasa kepedulian dan toleransi baik itu dalam berbedaq kenyakinan, pendapat, serta tidak mengucilkan orang lain yang berbeda dari apa yang ada pada dirinya.

d. Disiplin; yaitu tindakan yang menunjukan perilaku tertip dan patuh terhadap peraturan dan norma yang berlaku. La. Juli mengemukakan bahwa seorang pesilat tentunya akan selalu tertanam pada dirinya kedisplinan baik itu disiplin dalam menentukan segala hal tanpa melaranggar perintah Tuhan yang Maha Kuasa.

e. Cinta Tanah Air; yaitu cara berpikir, bertindak, dan berwawasan yang menempatkan kepentingann bangsa dan Negara diatas kepentingan diri dan kelompoknya. La. Maidhu mengemukakan bahwa awal dari terbentuknya perguruan silat pada dasarnya untuk mengajarkan masyarakat untuk membela tanah air dari penjajah yang ingin menguasai wilayah mereka sehingga tertanam pada diri mereka cinta tana air.

f. Bersahabat/ Komunikatif; yaitu sikap dan tindakan yang mendorong dirinya untuk mengasilkan sesuatu yang berguna bagi masyarakat, dan mengakui, serta mengormati keberasilan orang lain. La. Maidhu mengemukakan pesilat tentunya akan selalu ramah terhadap orang lain dan tidak sombong serta selalu mengargai orang-orang di sekitarnya baik itu yang lebih muda maupun yang lebih tua darinya.

g. Peduli Sosial 
Sikap dan tindakan yang selalu ingin memberi bantuan pada orang lain dan masyarakat yang membutuhkan. La. Husuma mengemukakan bahwa seorang pesilat tentunya akan tertanam pada dirinya peduli sesame baik itu berupa materi selagi yang bersangkutan sanggup memberikan apa yang di butuhkan oleh orang yang membutuhkan.

h. Tanggung Jawab; Sikap dan perilaku seseorang untuk melaksanakan tugas dan kewajibanya, yang seharusnya dia lakukan, teradap diri sendiri, masyarakat, lingkungan (alam, sosial, dan budaya), Negara dan tuan yang maha esa. La. Husuma mengemukakan bahwa ketika seorang pesilat diberikan tanggung jawab kepadanya selagi tidak melanggar perintah Tuhan yang Maha Kuasa akan selalu taat dan tidak melalaikan tanggung jawab tersebut.

\section{KESIMPULAN}

Berdasarkan uraian-uraian yang telah dikemukakan dalam pembahasan hasil penelitian pertama memasuki perguruan seni bela diri Ewa Wuna ada dua syarat yang dilakukan oleh sang murid yang ditawarkan oleh sang guru: Pertama feoti depake parakano dana dan banggai be lemo, yang kedua dofokadiu nekontu kaghito. Kedua syarat diterima dan disetujui oleh murid, maka guru mulai membimbing murid untuk melakukan gerak dasar silat. Hasil penelitian juga menunjukan bahwa pelaksanaan gerakan permainan seni bela diri Ewa Wuna terdiri atas dua tahap yaitu : (a) gerakan dasar silat seperti gerakan pica bunga, langka satu, langkah dua, langkah tiga, dan langkah empat, (b) Gerakan tahap kedua menyerang dan bertahan yang dimana gerakan menyerang dan bertahan dilakukan oleh dua orang murid. Kedua Perubahan yang terjadi dalam seni bela diri Ewa Wuna yang dikembangkan di Kecamatan Lasalepa Kabupaten Muna mengalami perubahan antara lain yaitu dari segi, pakaian, dan fungsi yaitu periode pada masa kerajaan hanya menggunakan pakaian serba hitam dan diikatkan sarung muna sedangkan sekarang pakaiannya hanya memakai pakaian biasa seperti pakaian modern yang kadang memakai sarung muna dipinggang dan kadang juga tidak. Segi fungsi pada masa kerajaan hanya digunakan sebagai pertahanan diri sedangkan pada masa sekarang digunakan sebagai hiburan pada acara-acara adat seperti, perkawinan, khitanan dan lain sebagainya. Ketiga nilai-nilai yang terkandung dalam permainan seni bela diri Ewa Wuna terdiri atas, (a) Nilai Religius yaitu bertakwa kepada Tuhan Yang Maha Esa,(b) Nilai seni yaitu menciptakan gerakan yang indah dan menarik untuk ditonton,(c) Nilai etika yaitu saling menghormati, saling menghargai dan mengandung nilai-nilai kesopanan., (d) Nilai sosial budaya yaitu menciptakan kehidupan yang harmonis dan kelestarian sedangkan budaya yang mengandung nilai-nilai keseluruhan budi pekerti.

\section{DAFTAR PUSTAKA}

Gazalba, Sidi. 1981. Pengantar Sejarah Sebagai Ilmu, Jakarta: Bharata Karya Aksara.

Koentjaraningrat. 1974. Beberapa Pokok Antropologi Sosial. Jakarta: PT Dian.

Koentjaraningrat. (1997).Teori-Teori Sosial Modern. Jakarta: Balai Pustaka.

Koentjaraningrat, 1987, Sejarah Teori Antropologi. Jakarta: UI Press.

Rohiman Notowidagdo. (1995). Pendidikan Agama dalam Masyarakat Modern, Seminar dan Lokakarya Nasional. Jakarta: Gramedia.

Samsuddin, Helius. 2007. Metodeologi Sejarah. Yogyakarta: Ombak.

Soekanto. 1998. Sosiologo Sebagai Pengantar. Jakarta: Rajawali Pres.

Soekanto. 1985. Sosiologi suatu pengantar. Jakarta : CV Rajawali 